\title{
Effect of Yoga Basti in Sandhivata w.s.r. to Osteoarthritis of Knee joint
}

\author{
Research Article
}

\section{Daksha Rathod $^{1 *}$, Kalpesh Dattani ${ }^{2}$}

\begin{abstract}
1. Lecturer in Panchakarma Department, G.J.Patel Institute of Ayurveda \& Research Center, New V.V.Nagar, Anand, Gujarat.
\end{abstract} 2. Lecturer in Balaroga, Shree Gulabkuvarba Ayurved Mahavidhyalaya, Jamanagar.

\begin{abstract}
Sandhivata (Osteoarthritis) is one of the Vataja vyadhi (disease due to Vata Dosha) and most common degenerative disease seen in old age people. The Ayurvedic approach to the management of Sandhivata is to provide the complete cure. Objective of the present study was to evaluate the effect of Erandamooladi Niruha Basti and Dashamooladi Anuvasana Basti as Yoga Basti in Sandhivata w.s.r to osteoarthritis of knee joint. Method: 30 patients fulfilling the inclusion criteria of Sandhivata were randomly selected in a single group and treated with Yoga Basti [Dashmooladi Anuvasan Basti and Erandmooladi Niruha Basti] daily in the morning for a period of 8 days. Clinical signs and symptoms were given suitable scores according to their severity and assessed based on pre and post data gathered through pre-designed research clinical proforma. The results having ' $\mathrm{P}$ ' value less than 0.0001 was considered to be statistically significant in this study. Result: All the patients in the group showed highly significant improvement in all the symptoms. Pain relieved $80.77 \%$, stiffness relieved $84.39 \%$, fatigue relieved 100\%, restricted movement reduced by $100 \%$ and deformity reduced by $74.15 \%$. Conclusion: Yoga Basti is found effective in the management of Sandhivata with reference to osteoarthritis of knee joint.All the patients responded to the given treatment without any adverse effects and complications. Mild to marked relief was found in all the symptoms of Sandhivata .
\end{abstract}

Keywords: Osteoarthritis, Sandhivata, Vatavyadhi, Yoga basti.

\section{Introduction}

According to Ayurveda, freedom from disease is not only health. To be healthy, a person should be happy mentally, physically, socially and also spiritually. Imbalance of Dosha is termed as Roga. Among Tridosha, Vata is responsible for almost all disease(1).

Sandhivata is described under Vatavyadhi in all the Samhita and Sangraha Grantha. In Vriddhavastha, all Dhatus undergo Kshya, thus leading to Vataprakopa and making individual prone to many diseases. Among them Sandhigata Vata stands top in the list. Acharya Charaka was the first person who described the disease separately named "Sandhigata Anila", but has not included under 80 types of Nanatmaja Vyadhi(2). Acharya charaka has considered Vata Vyadhi as a Maharoga(3). Till to date Sandhigata Vata is a challenging disease and is the number one cause of disability in industrialized countries.According to world health organization osteoarthritis(sandhivata) is the second commonest musculoskeletal problem in the world populations coming to $30 \%(4)$.

*Corresponding Author:

Daksha Rathod

Lecturer in Panchakarma Department,

G.J.Patel Institute of Ayurveda, New V.V.Nagar.

Anand, Gujarat

E-mail id: daxarathod@yahoo.com
The trouble of Sandhis by Prakupita Vata is the main phenomena in Samprapti of Sandhigata Vata. Sandhis come under the Madhyama Roga Marga and thus, involvement of Madhyama Roga Marga, Vata Dosha and Dhatukshaya figures disease Kashta Sadhya (difficult to treat.)(5)

Osteoarthritis is the most common articular disorder begins asymptomatically in the 2nd and 3rd decades and is extremely common by age 70. Almost all persons by age 40 have some pathologic change in weight bearing joint. $25 \%$ females and $16 \%$ males have symptomatic OA .Indians are said to have increased knee OA as compared to western population(6). The disease Osteoarthritis may be regarded as a reward of longevity. It seems man has paid price for standing on hind limbs in form of osteoarthritis of weight bearing joints of the body. The disease arthritis causes work disability. It limits everyday activities such as walking, dressing, bathing etc., thus making individual handicapped. No treatment is available which can prevent the disease process. In Western Medical science, mainly analgesics, anti-inflammatory drugs or surgery are the options for the treatment of Osteoarthritis, don't provide remarkable recovery, but causes great adverse effect. Researchers are trying their level best for making drugs which can prevent or slow down or reverse joint damage. A common treatment for Vata Vyadhi has been described by Acharya Vagabhatai.e. repeated use of Snehana (Oleation 
therapy) and Swedana (Sudation therapy), Basti (Enema) and Mrudu Virechana(Mild Purgative)(7). Acharya Sushruta has mentioned the treatment for Sandhigata Vata clearly i.e. Snehana, Upanaha, Agnikarma, Bandhana and Unmardana(8). Panchakarma is a very unique therapeutic procedure, because of its preventive, promotive, prophylactic and rejuvenative properties as well as providing a radical cure.

Among panchakarma basti karma is considered as "Ardha chikitsa" and "Sarvakari". Basti are of many types depending on numbers, ingredients and needs. Yoga basti is one among them. In yoga basti, 8 basti are given in total, in this procedure first anuvasana basti should be given followed by 3 niruha and anuvasana basti given alternatively and at the after that one anuvasna basti should be given. Dashamoola taila is indicated in vata vyadhi (9) and Erandamooladi kwatha (10) is useful for niruha basti in vata vyadhi.

A humble attempt to find a combination of palliative therapy, which is facile, uncomplicated and economical, is made in the present context. The entire study has two major ramifications as 1. Conceptual study of the literature of both Sandhivata and osteoarthritis of knee are reviewed, 2The clinical study observations, results, discussion, conclusion and bibliography are documented.

Aim:

An attempt has been made to study in detail about sandhivata w.s.r to osteoarthritis of knee joint to study basti karma in detail and to evaluate the effect of Erandamooladi niruha basti and Dashamooladi anuvasana basti as yoga basti in sandhivata.

\section{Materials and Methods: \\ Drug:}

Anuvasan basti with Dashmool tail - Dashmool tail which was readily prepared by Baidhnath pharmacy, was taken and was administered in form of anuvasan basti as per the schedule of yoga basti mentioned. Ingredients were given in details in table- 1. 1)dashmool tail $=150 \mathrm{ml}, 2$ ) saindhav lavan= 1 pinch, 2)erandamuladi niruh basti erandmuladi niruh basti was prepared by mixing the drugs in following proportion and was administered in the form of niruh basti as per the schedule of yoga basti.1)honey- $80 \mathrm{ml}$ )saindhav lavan-10 gm3)sneh[dashmool tail]-150 ml 4)kalka [erandmula kalka]-20 gm 5)erand muladi niruh basti kwath churn with water-350 $\mathrm{ml}$, Total quantity= approximately $600 \mathrm{ml}$.

\section{Table-1 Ingredients of Yoga basti}

\begin{tabular}{|l|l|l|}
\hline Bilva & Agnimantha & Syonaka \\
\hline Patala & Gambhari & Shalaparani \\
\hline Prishnaparni & Gokshura & Brihati \\
\hline Kanthakari & Rasana & Nirgundi \\
\hline Sarshapa & Erandamula & Palasha \\
\hline Ashwagandha & Atibala & Guduchi \\
\hline Punarnava & Aragvadha & Devadaru \\
\hline
\end{tabular}

\begin{tabular}{|l|l|l|}
\hline Madanaphala & Shatahva & Priyangu \\
\hline Pippali & Maduka & Bala \\
\hline Daruharidra & Kutaja & Mustaka \\
\hline Shatapushpa & Hapusha & Til Taila \\
\hline Madhu & Saindhva & Gomutra \\
\hline Bilva & Agnimantha & Syonaka \\
\hline Patala & Gambhari & Shalaparani \\
\hline Prishnaparni & Gokshura & Brihati \\
\hline Kanthakari & Rasana & Nirgundi \\
\hline Sarshapa & Erandamula & Palasha \\
\hline Ashwagandha & Atibala & Guduchi \\
\hline Punarnava & Aragvadha & Devadaru \\
\hline Madanaphala & Shatahva & Priyangu \\
\hline Pippali & Maduka & Bala \\
\hline Daruharidra & Kutaja & Mustaka \\
\hline Shatapushpa & Hapusha & Til Taila \\
\hline Madhu & Saindhva & Gomutra \\
\hline
\end{tabular}

\section{Sources of data.}

Patients who attended the OPD and IPD of B.M.J Ayurvedic Medical College, Hospital, Gajendragad. Patients of either sex diagnosed as being suffering from sandhivata were selected for the study.

\section{Sampling method.}

Random sampling method was followed and sampling was done from the population. Patients with features satisfying the inclusion criteria were selected and registered with the help of special Performa for the study.

\section{Inclusion criteria.}

Patients between age group of 40-70 years, having classical signs and symptoms of sandhivata, positive to goniometer test and suitable for Basti Karma are included in study

\section{Exclusion criteria.}

Patients who are not fit for basti karma, having other systemic disorders and below 40 years and above 70 years were excluded from the study.

\section{Study Design}

It was a single group clinical study in which 30 patients of Sandhivata who were diagnose based on signs and symptoms were allocated for Yoga Basti.

\section{Intervention:}

Table-2:Diagnosed patient were adminstered anuvasan (A.B) and niruh basti (N.B) as per Yoga Basti schedule.

\begin{tabular}{|l|l|l|l|l|l|l|l|l|}
\hline Days & 1 & 2 & 3 & 4 & 5 & 6 & 7 & 8 \\
\hline Basti & AB & NB & AB & NB & AB & NB & AB & AB \\
\hline
\end{tabular}


After adminstering basti patient was asked to follow pathya - apthya (diet restriction) as per the rule of Basti. For the change in the condition of patient was examine before treatment on the first day and after treatment on the 24 day based on the subjective and objective parameters.

\section{CRITERIA FOR ASSESMENT-}

Table-3: Subjective and Objective parameters

\begin{tabular}{|c|c|c|c|c|c|c|}
\hline Grade & Pain & Stiffness & Tenderness & $\begin{array}{l}\text { Range of } \\
\text { movement } \\
\text { flexion at } \\
\text { knee joint }\end{array}$ & Oedema & $\begin{array}{l}\text { Knee flexion by } \\
\text { Goniometer }\end{array}$ \\
\hline $\begin{array}{c}\text { Grade-0 } \\
\end{array}$ & No pain & $\begin{array}{l}\text { No } \\
\text { stiffness }\end{array}$ & No tenderness & $\begin{array}{l}101-120 \\
\text { degree } \\
\text { flexion }\end{array}$ & Absent & $\begin{array}{ll}\text { Up to } & 130 \\
\text { Flexion } & \text { and } \\
\text { above (Normal) }\end{array}$ \\
\hline Grade-1 & $\begin{array}{l}\text { Pain observed } \\
\text { on excessive } \\
\text { work with joint } \\
\text { involvements, } \\
\text { normal routine } \\
\text { activities will } \\
\text { not being get } \\
\text { hampered }\end{array}$ & $\begin{array}{l}\text { Mild } \\
\text { stiffness }\end{array}$ & $\begin{array}{l}\text { Patient says it } \\
\text { is paining }\end{array}$ & $\begin{array}{l}81-100 \\
\text { degree } \\
\text { flexion }\end{array}$ & $\begin{array}{l}\text { Swelling } \\
\text { slightly } \\
\text { covering only } \\
\text { the bony } \\
\text { prominence. }\end{array}$ & $\begin{array}{l}\text { Up to } 120 \\
\text { Flexion (Mild) }\end{array}$ \\
\hline Grade-2 & $\begin{array}{l}\text { Pain increased } \\
\text { on little work- } \\
\text { involving joint } \\
\text { movement, but } \\
\text { gets relieved by } \\
\text { rest.Normal } \\
\text { routine } \\
\text { activities being } \\
\text { slightly } \\
\text { hampered. }\end{array}$ & $\begin{array}{l}\text { Moderate } \\
\text { stiffness }\end{array}$ & $\begin{array}{lr}\text { Grade } & 1 \\
\text { patient } & \text { winces } \\
\text { and } & \text { with } \\
\text { draws } & \text { the } \\
\text { affected } & \end{array}$ & $\begin{array}{l}61-80 \\
\text { degree } \\
\text { flexion }\end{array}$ & $\begin{array}{l}\text { Completely } \\
\text { covering all } \\
\text { the body } \\
\text { prominence }\end{array}$ & $\begin{array}{ll}\text { Up to } 100 \\
\text { Flexion } \\
\text { (Moderate) }\end{array}$ \\
\hline Grade-3 & $\begin{array}{l}\text { Severe and } \\
\text { persistent pain } \\
\text { with sleep } \\
\text { disturbance and } \\
\text { inability to carry } \\
\text { on the normal } \\
\text { activities. }\end{array}$ & $\begin{array}{l}\text { Severe } \\
\text { stiffness }\end{array}$ & $\begin{array}{l}\text { Does not } \\
\text { allow the } \\
\text { effected joint } \\
\text { to be touched. }\end{array}$ & $\begin{array}{l}0-60 \\
\text { degree } \\
\text { flexion }\end{array}$ & $\begin{array}{l}\text { Completely } \\
\text { covering the } \\
\text { joint }\end{array}$ & $\begin{array}{l}\text { No } \\
\text { improvement on } \\
\text { Knee flexion } \\
\text { and } \quad \text { above. } \\
\text { (Severe) }\end{array}$ \\
\hline
\end{tabular}

All the clinical symptoms of sandhivata w.s.r. to osteoarthritis of knee joint. Vatapurnadhrutisparsh, sandhi vedan, aatop and sandhi sethilayata.

Objective parameters: Goniometer Test Assessment of response to the treatment

The state of disease was assessed before treatment based on the assessment criteria. The changes in the scoring were noted during and after the intervention.

\section{Criteria for overall assessment:}

The sum points of all 5 parameters of assessment before, during and after treatment were taken into consideration to assess the total effect of the therapy. It was graded in percentage of relief in the signs and symptoms.1. Poor $0-20 \%, 2$. Average improvement 20 - 40\%, 3. Moderate improvement 40 - 60\%, 4. Good improvement $60-80 \%$, 5. Excellent improvement 80$100 \%$.

\section{Statistical Analysis:}

The effect of Yogabasti was assessed.
Descriptive data that included mean standard deviation (SD) standard error (SE); ' $T$ ' value and percentage were calculated for all the variables in each group. Post treatment changes were assessed by paired "T" test and difference between groups was assessed by unpaired "T" test. For all the tests, a 'p' value of 0.005 or less was considered for statistical significance.

Observations and Results:

TABLE-4 Age wise distribution of patients

\begin{tabular}{|l|l|l|}
\hline \multirow{2}{*}{ Age (years) } & \multicolumn{2}{|l|}{ SINGLE Group } \\
\cline { 2 - 3 } & No. & \% \\
\hline $40-45$ & 8 & 26.67 \\
\hline $46-50$ & 5 & 16.66 \\
\hline $51-55$ & 2 & 6.66 \\
\hline $56-60$ & 6 & 20 \\
\hline $61-65$ & 4 & 13.33 \\
\hline $66-70$ & 5 & 16.66 \\
\hline
\end{tabular}


Table-5 Sex wise distribution of patients

\begin{tabular}{|l|l|l|}
\hline \multirow{2}{*}{ Sex } & \multicolumn{2}{|l|}{ Single Group } \\
\cline { 2 - 3 } & No. & \% \\
\hline Male & 14 & 46.6 \\
\hline Female & 16 & 53.3 \\
\hline
\end{tabular}

Table No: 6 Distribution of patients based on Occupation

\begin{tabular}{|l|l|l|}
\hline \multirow{2}{*}{ Nature of work } & Group A \\
\cline { 2 - 3 } & No & $\%$ \\
\hline Mild strenous & 4 & 13 \\
\hline Moderate strenous & 18 & 60 \\
\hline Sedentary & 8 & 27 \\
\hline
\end{tabular}

Table no: 7 Distribution of patients according to duration of illness

\begin{tabular}{|l|l|l|}
\hline \multirow{2}{*}{ Duration of illness } & Group A \\
\cline { 2 - 3 } & No & $\%$ \\
\hline$<1$ year & 8 & 27 \\
\hline 1-3 years & 17 & 57 \\
\hline 3-5 years & 3 & 10 \\
\hline$>5$ years & 2 & 6 \\
\hline
\end{tabular}

In the current study observations were made on various grounds to have evidence on various factors. In total 30 patients were registered, who were suffering from sandhivata [OA of knee joint] for this single group study.Maximum incidence of sandhivata was found in the age group of 40-45 years.(table-4) Incidence of sandhivata was found to be a maximum of $53.3 \%$ in females.(table-5).Maximum numbers of patients registered for the study having moderate strenuous work with a percentage of $60 \%$ followed by mild strenuous work with a percentage of $13 \%$ and sedentary work with a percentage of $27 \%$.(Table- 6 ).Among 30 patients of the study $66.67 \%$ patient were used to do Vyayama and the remainning did not. $60 \%$ of patients weighed between $61-70 \mathrm{kgs}, 3 \%$ weighed between $71-80 \mathrm{kgs}, 17 \%$ between $51-60 \mathrm{kgs}, 10 \%$ between $81-90 \mathrm{kgs}$ and $10 \%$ had weight between 41-50 kgs. Maximum incidence of about $57 \%$ of patients had duration of illness between 1$3 y r s$ followed by $27 \%$ of patients with duration of less than 1 year. $10 \%$ of patients gave history of illness between 3-5 yrs and 6\% had the complaints for duration of more than 5 yrs (Table no-7).

\section{Data related to Diseases:}

Aggravating factors in sandhivata patients are walking, climbing stairs and squatting were counted as aggravating factors by all the patients where as standing aggravated the signs and symptoms in $83 \%$ of patients.All the 30 patients, which means $100 \%$ had Vatapurna dhruti sparsha, Sandhi vedana, Sandhi Atopa, Sandhi saithilyata.Maximum incidence of about $57 \%$ of patients had duration of illness between 1-3yrs followed by $27 \%$ of patients with duration of less than 1 year. $10 \%$ of patients gave history of illness between 3-5 yrs and $6 \%$ had the complaints for duration of more than 5 yrs.

\section{Discussion:}

Sandhivata is a disorder dominated by pain affecting the Sandhi (joint). It is caused by morbid Vata Dosha. Kapha Dosha may also be involved in the clinical presentation. The vitiated Dosha or Doshas afflict the Mamsa, Asthi and Snayu. It is more evident in Asthi Dhatu with which Vayu has Ashraya-Ashrayee Bhava Sambhanda $(11,12,13)$

As far as Basti goes, it is thought to be an ultimate solution for eradication of Vata Dosha and Vata vitiation is the main cause of SANDHIVATA. Moreover, it also has action on the vitiated Pitta, Kapha and Rakta .According to Ayurveda the Virya of ingredients used in the Basti, gets absorbed and then through general circulation reaches at the site of lesion and relieves the disease(14). That's why Acharya Sushruta has mentioned that by using the different ingredients, Basti can be cured Paittika, Kaphaja, Raktaja, Sansargaja and Sannipatika disorders also though, it is the best treatment for Vata Dosha (15).

In yoga basti, 8 basti are given in total, in this procedure first anuvasana basti should be given followed by 3 niruha and anuvasana basti are given alternatively and at the end again one anuvasna basti should be given. In the beginning, one Anuvasana Basti and at the end, 3 Anuvasana Basti were given for the purpose of oleation.Dashamoola taila is indicated in vata vyadhi and Erandamooladi kwatha is useful for niruha basti in vata vyadhi. Erandamooladiniruha basti has been classically indicated in vitiated Vata condition and specially in Vata vitiated in Janu pradesha and hence the same drug was chosen for present study. Ayurveda gives emphasis on various karmas in treating the foresaid ailment, amongst which Basti Chikitsa is considered to be the best for Vata dosha, which is the main culprit in sandhivata. All of symptoms including joint deformity are mainly due to Vata vitiation. Drugs used here for Basti Karma are mainly acting on Vata dosha and regulates Vata dosha activity all over the body. Seers mentioned qualities of Dashmoola like Shothahara (anti-immflamatory), Vatahara( nullifies vata dosha), ushna (hot), etc(16). Studies also reported anti immflamatory, analgesic(17), and anti pyretic(18), effect of Dashamoola.

Eranda ( Ricinous communis) is very well known Vatahara drug. Studies reported Antioxidant activity (19), Anti-Inflammatory and free radical scavenging activity(20), Central analgesic activity(21), Antitumour activity(22) of eranda. All these drugs are help to improve diseased condition and improves quality of life too.

As per age-wise distribution, maximum numbers of patients $(26.67 \%)$ in this study were in the age group of 40-45 years. This is the age wherein Hani (deterioration) of Dhatus starts(23) In this study, maximum numbers of patients $(53.3 \%)$ were females. Sex hormones have long been considered a possible factor in the systemic predisposition to OA, especially in women. $(24,24,25)$ Nearly $27 \%$ of patients had chronicity below 1 year, whereas $67 \%$ of patients were between 1 to 5 years and remaining $6 \%$ of patients were more than 5 years. 
Significant results $(\mathrm{P}<0.0001)$ were found in all the cardinal symptoms - Sandhiruja (pain), Shotha (swelling), tenderness and crepitus. There was significant improvement in walking velocity. This proves that Yoga basti is effective treatment in the form of Dashmoola tail anuvasan basti and Erandmuladi niruha basti in Sandhivata. Pain and crepitus are mainly due to Vata Dosha and above data proves that Yoga basti controls Vata Dosha and relieves these symptoms.

\section{Effect on Cardinal Symptom:}

TABLE NO-8 Presentation of Statistical Data

\begin{tabular}{|l|l|l|l|l|l|l|l|l|}
\hline Criteria & & Pain & Stiffness & Swelling & Fatigue & $\begin{array}{l}\text { Restricted } \\
\text { movement }\end{array}$ & Deformity & Goniometer \\
\hline Mean & BT & 2.6 & 2.37 & 1.9 & 2.6 & 2.3 & 1.43 & 1.53 \\
\hline & AT & 0.5 & 0.37 & 0.33 & 0.5 & 0.43 & 0.37 & 0.4 \\
\hline Mean Diff & & 2.1 & 2 & 1.57 & 1.2 & 1.87 & 1.06 & 1.13 \\
\hline$\%$ & & 80.77 & 84.39 & 100 & 87.6 & 100 & 74.15 & 73.86 \\
\hline SD & BT & 0.5 & 0.49 & 0.66 & 0.61 & 0.79 & 0.57 & 0.63 \\
\hline & AT & 0.51 & 0.49 & 0.48 & 0.38 & 0.5 & 0.49 & 0.5 \\
\hline SEM & BT & 0.009 & 0.009 & 0.12 & 0.11 & 0.15 & 0.1 & 0.11 \\
\hline & AT & 0.009 & 0.009 & 0.009 & 0.07 & 0.009 & 0.009 & 0.9 \\
\hline SED & & 0.13 & 0.127 & 0.149 & 0.132 & 0.172 & 0.137 & 0.146 \\
\hline t-Value & & 16.1555 & 15.8038 & 10.5005 & 9.0986 & 10.8678 & 7.7849 & 7.7372 \\
\hline N & & 30 & 30 & 30 & 30 & 30 & 30 & 30 \\
\hline $\begin{array}{l}\text { Degrees of } \\
\text { Freedom }\end{array}$ & & 58 & 58 & 58 & 58 & 58 & 58 & 58 \\
\hline CI & LL & 1.84 & 1.75 & 1.27 & 0.94 & 1.52 & 0.79 & 0.84 \\
\hline & UL & 2.36 & 2.25 & 1.87 & 1.46 & 2.21 & 1.34 & 1.43 \\
\hline P-Value & & $\mathrm{P}<0.0001$ & $\mathrm{P}<0.0001$ & $\mathrm{P}<0.0001$ & $\mathrm{P}<0.0001$ & $\mathrm{P}<0.0001$ & $\mathrm{P}<0.0001$ & $\mathrm{P}<0.0001$ \\
\hline Significance & & ESS & $\mathrm{ESS}$ & $\mathrm{ESS}$ & $\mathrm{ESS}$ & $\mathrm{ESS}$ & $\mathrm{ESS}$ & $\mathrm{ESS}$ \\
\hline
\end{tabular}

Table: 9 Overall Result of Treatment

\begin{tabular}{|l|l|l|l|}
\hline S.No & CRITERIA & NUMBER & PERCENTAGE \\
\hline 1 & Poor Improvement [0-25\%] & 0 & - \\
\hline 2 & Mild Improvement [26-50] & 0 & - \\
\hline 3 & Moderate Improvement [51-75] & 7 & 23.33 \\
\hline 4 & Marked Improvement [76-99] & 17 & 56.67 \\
\hline 5 & Cured [100] & 6 & 20 \\
\hline
\end{tabular}

All the Patients showed highly significant relief, in the symptoms of pain percentage wise relief of $80.77 \%$. Thus, the best response is seen among the patients(Table no- 8). This is clear from the above discussion that all the therapies have reduced the pain in the patients of Sandhivata, Pain is produced mainly by Vata Prakopa and the Basti is the best treatment for Vata. So, this may be one of the reasons that the relief has been found. Stiffness was $84.39 \%$ relieved and it was statistically significant $(\mathrm{P}<0.0001)$. Stiffness happens to be a subjective criterion and was graded based on its Gradings. There was improvement observed in this feature with treatment in the group. The result was statistically highly significant with $P$ value being less than 0.0001 . Swelling was $100 \%$ relived and it was statistically significant $(\mathrm{P}<0.001)$. Fatigue was $87.6 \%$ relieved and it was statistically significant $(\mathrm{P}<0.0001)$. Effect on restricted movement was $100 \%$ relived and it was statistecally significant $(\mathrm{P}<0.0001)$. Effect on Deformity:Deformity was $74.15 \%$ relived and the result were statistecally significant(table- 8 ). 


\section{Conclusion:}

The purpose of the present study was "To Evaluate the effect of Yoga basti in Sandhivata w.s.r. to osteoarthritis of knee joint" The conclusions were drawn after logical interpretation of the results obtained in the preceding clinical study. Sandhivata can be well equated with osteoarthritis in modern parlance. There is no explicit citation regarding nidana and samprapthi with respect to Sandhivata. It was apparent from the study of yoga basti in sandhivata w.s.r to osteoarthritis of knee joint showed invigorating result in alleviating the presentations of SV. It was also observed that yoga basti when given would yield best results. Hence it can be concluded that Yoga basti with dhasmool tail anuvasan basti and erandmuladi niruha basti which is economical and effective, give relief from the symptoms of sandhivata.

\section{References:}

1. Gangasahaya Pandey, The Charaka Samhita Of Agnivesha With Ayurveda Deepika Commentary Of Chakrapani Dutta And With 'Vidyotini' Hindi Commentary By Pt Kashinath Shastri, Chaukhamba Sanskrit Sthana, 1997, Varanasi 5th Edition, Chikitsa Sthan, 28th Chapter, Sloka No-3, Page No775 .

2. Gangasahaya Pandey, The Charaka Samhita Of Agnivesha With Ayurveda Deepika Commentary Of Chakrapani Dutta And With 'Vidyotini' Hindi Commentary By Pt Kashinath Shastri, Chaukhamba Sanskrit Sthana, 1997, Varanasi 5th Edition, Chikitsa Sthan, 28th Chapter, Sloka No-37, Page No -783 .

3. Gangasahaya Pandey, The Charaka Samhita Of Agnivesha With Ayurveda Deepika Commentary Of Chakrapani Dutta And With 'Vidyotini' Hindi Commentary By Pt Kashinath Shastri, Chaukhamba Sanskrit Sthana, 1997, Varanasi 5th Edition, Indriya Sthana, 9th Chapter, Sloka No-8, Page No-368.

4. API-TM, 19th Chapter, Section-5, Page No 1151.

5. Gangasahaya Pandey, The Charaka Samhita Of Agnivesha With Ayurveda Deepika Commentary Of Chakrapani Dutta And With 'Vidyotini' Hindi Commentary By Pt Kashinath Shastri, Chaukhamba Sanskrit Sthana, 1997, Varanasi 5th Edition, Viman Sthana, 4th Chapter, 7th Sloka, Page No-587.

6. API-TM, 19th Chapter, Section-5, Page No1 152.

7. Vaidya Yadunandana, Astangahrdaya Of Vagabhata Edited With 'Vidyotini' Hindi Commentary By Kaviraja Gupta, Chaukhambha Prakashan, Varanasi, Reprint 2007, 13th Chapter 1st, 2nd, 3rd Slokas, Page No 96, 97.

8. Vaidya Yadavaji Trikamji Acharya, Susrutha Samhita With Nibandhasangraha Commentary Of Sri Dalhana Acharya, Chaukhambha Surbharati Prakashan, Varanasi, Reprint2012, Chikitsa Sthana, 4th Chapter, 8th Sloka, Page No-820.

9. Siddhi Nandan Mishra, Bhaishaja Ratnavali Of Kaviraj Govindadassen With Siddhiprabha Hindi Commentary, Chaukhambha Surbharathi Prakashana 2005, Varanasi, 1st Edition, Chapter No 65, Sloka No-111, 112, Page No-713.
10. Gangasahaya Pandey, The Charaka Samhita Of Agnivesha With Ayurveda Deepika Commentary Of Chakrapani Dutta And With 'Vidyotini' Hindi Commentary By Pt Kashinath Shastri, Chaukhamba Sanskrit Sthana, 1997, Varanasi 5th Edition, Part 2, Siddhisthana, Chapter 3, Sloka 38-42, Page No-917.

11. Bhishagacharya Harishastri Paradekara Vidya, Astangahridayam Composed By Hemadri, Choukhamba Orientalia 2002, Varanasi, 9th Edition, Sutra Sthana 11th Chapter, 26th Sloka, Page No186 .

12. Gangasahaya Pandey, The Charaka Samhita Of Agnivesha With Ayurveda Deepika Commentary Of Chakrapani Dutta And With 'Vidyotini' Hindi Commentary By Pt Kashinath Shastri, Chaukhamba Sanskrit Sthana, 1997, Varanasi 5th Edition, Part 2, Chikitsa Sthana, 28th Chapter, 12th Sloka, Page No778 .

13. Gangasahaya Pandey, The Charaka Samhita Of Agnivesha With Ayurveda Deepika Commentary Of Chakrapani Dutta And With 'Vidyotini' Hindi Commentary By Pt Kashinath Shastri, Chaukhamba Sanskrit Sthana, 1997, Varanasi 5th Edition, Part 2, Chikitsa Sthana, 28th Chapter, 15th 16th 17th Slokas, Page No-779.

14. Gangasahaya Pandey, The Charaka Samhita Of Agnivesha With Ayurveda Deepika Commentary Of Chakrapanidutta And With 'Vidyotini'hindi Commentary By Pt Kashinath Shastri, Chaukhamba Sanskrith Sansthan 1997, 5th Edition, Siddhi Sthana, 1st Chapter, 41th Sloka, Page No-887.

15. Vaidya Yadavaji Trikamji Acharya, Susrutha Samhita With Nibandhasangraha Commentary Of Sri Dalhana Acharya, Chaukhambha Surbharati Prakashan, Varanasi, Reprint2012, Chikitsa Sthana, 35th Chapter, 3rd Sloka.

16. Gopal C Nanda1*, R K Tiwari2ayushdhara, Shothahara Activities Of Dashamoola Dravyas As An Anti Inflammatory Formulation With Special Reference To Charak- A Review January February 2016 | Vol 3 | Issue 1, 479-485.

17. Gopal C Nanda1*, R K Tiwari2ayushdhara, Shothahara Activities Of Dashamoola Dravyas As An Anti Inflammatory Formulation With Special Reference To Charak- A Review | January February 2016 | Vol 3 | Issue 1, 479-485.

18. Dawane Js, Pandit V, Borole K. Experimental Evaluation Of Antipyretic Activity Of Aqueous Extract Of Dashamula. Spatula Dd, 2012; 2(1): 1721

19. Singh P.P Et Al, Activity Guided Isolation Of Antioxidants From The Leaves Of Ricinuscommunis L. Food Chemistry 2009; 114(3): $1069-1072$.

20. Ilavarasan R. Et Al, Anti-Inflammatory And Free Radical Scavenging activity of Ricinus Communis Root Extract. Journal of Ethnopharmacology 2006; 103: 478- 480

21. Ferraz A.C. Et Al. Pharmacological Evaluation Of Ricinine, A Centralnervous System Stimulant Isolated From Ricinus Communis.Pharmacology Biochemistry And Behavior 1999; Vol. 63: No. 3: 367-375. 
22. Lin J. Y. Et Al. Studies On The Antitumour Lectins Isolated From The Seeds Of Ricinus Communis (Castor Bean). Toxicon 1986; Vol. 24: No. 8: 757765.

23. Vyadhisamuddeshiya Adhyaya, Sushruta Sushruta Samhita, Sutra Sthana., 24/8. In: Ambikadatta Shastri., editor. 14th ed. Varanasi: Chaukambha Sanksrit Prathishtan; 2003. p. 101.

24. Oldenhave A, Jaszmann LJ, Haspels AA, Everaerd WT. Impact of climacteric on well-being. A survey based on 5213 women 39 to 60 years old. Am J Obstet Gynecol.1993;168:772-80. [PubMed]

25. Lindsay R. Estrogen deficiency. In: Riggs BL, Melton, editors. Osteoporosis: etiology, Diagnosis and Management. 2nd ed. Philadelphia: LippincottRaven; 1995. pp. 133-60.

26. Kritz-Silverstein D, Barrett-Connor E. Early menopause, number of reproductive years, and bone mineral density in postmenopausal women. Am J Public Health. 1993;83:983-8.[PMC free article] [PubMed] 